FACTA UNIVERSITATIS

Series: Law and Politics Vol. 15, N 4, 2017, pp. 397 - 409

https://doi.org/10.22190/FULP1704397M

Review Paper

\title{
ECONOMIC ANALYSIS OF HEALTHCARE PROTECTION
}

\author{
UDC 364.32
}

\author{
Aleksandar Mihajlović \\ University of Niš, Faculty of Law, Niš, Republic of Serbia
}

\begin{abstract}
The particular nature of healthcare protection and healthcare insurance requires government intervention. Besides legal aspects, such as the question of social rights, there are purely economic reasons for the government actions. First, being a particularly important public good, healthcare protection could not be regulated by free market in full. There is no perfect model of healthcare protection and healthcare insurance. The socioeconomic change of the forms of government has affected the models of healthcare protection and healthcare insurance throughout history. Despite a commonly used phrase "free" healthcare insurance and healthcare protection, the fact remains that it is not free but paid by a society and its members. Although proclaimed by international acts, constitutions and laws, these rights are exercised in the form of the so-called programme principles whose accomplishment primarily depends on the economic wealth of one society. Also, more investment into the field of healthcare insurance does not necessarily imply a better health or a longer life span of the inhabitants of one society. Therefore, available resources are to be used efficiently and economically so that the best possible effects of healthcare protection are achieved within the range of these resources.
\end{abstract}

Key words: healthcare protection, healthcare insurance, government intervention, public goods, healthcare market.

\section{INTRODUCTORY NOTES}

The concept of a social state presupposes a state which provides its citizens with a certain number of compulsory services in the field of healthcare protection and healthcare insurance. The quality and number of these services depends not only on the economic wealth of the state but also on the fact whether the state is either market-oriented or inclined towards the government intervention in this field. Notwithstanding the fact that the rights to healthcare protection and healthcare insurance fall into the category of the social and economic rights guaranteed by international and national legal acts and regulations, there are purely economic reasons for government interventions in this area of human life.

Received November $5^{\text {th }}, 2017 /$ Accepted November $27^{\text {th }}, 2017$

Corresponding author: Aleksandar Mihajlović, LL.M., "PhD student

Faculty of Law, University of Niš, Trg Kralja Aleksandra 11, Niš, Serbia

E-mail: aleksandarmihajlovic91@ yahoo.com 
This paper discusses the concepts of healthcare protection and healthcare insurance, their regulation and funding models, while indicating the basic legal acts and measures of the Republic of Serbia appertaining to this field. The final section of the paper examines the structure of the healthcare market and emphasizes its characteristics that make it particular and nonstandard, and thus prone to the government intervention.

\section{THE CONCEPT OF HEALTHCARE PROTECTION}

Health has long been the matter of government and state concern, and thus also a legal matter. Compulsory measures aimed at protection of public health are known to have existed even in the oldest human communities (isolation of infected individuals, compulsory sanitary measures, systematic treatment and hospitalization of the diseased, medical protection standards). These measures have bred a specific area of legal practice - Health or Medical Law. The process of fulfilling conditions necessary for exercising the right to health is a complex one, including the establishment of the system of healthcare and infrastructure, legislation, health development and prevention plans, training of medical staff, research in the field of medicine, health education, improvement of environmental, healthcare and work protection, measures for health prevention and enhancement (Jašarević, 2013: 109, 111).

The right to healthcare or healthcare protection belongs to the group of socioeconomic rights. ${ }^{1}$ Actually, there are two groups of rights: social and economic ones. Economic rights are primarily related to the rights referring to the factors of work (capital, workforce, state). They create a possibility for individuals to make profit and earn a living by their capital or workforce investments. Social rights ensure social security, ${ }^{2}$ i.e. they provide guaranteed assistance to individuals and groups of people with an inadequate or no income. These two groups of human rights are so intertwined in real life that they are always discussed together, which is reflected in the term used for them. Although they are related to different matters, they are interconnected owing to their common goal: to attain the level of social security that guarantees human dignity (Jašarevic, 2013: 86). These rights are the product of an altered nature of the contemporary state. Namely, while a state was just a legal and political entity at the time of liberalism, it is now also a social and cultural community interfering in economy with the purpose of achieving certain social goals (Marković, 2015: 482).

\footnotetext{
${ }^{1}$ Socio-economic rights were recognized as human rights some time later compared to the civil and political rights. This is why they are called the second generation rights. The reason for their late recognition and inadequate appreciation lies in their being rather particular in nature, quite vague and hard to realize. Namely, while civil and political rights are enough to be just proclaimed and not directly jeopardized, it takes an intensive and long-term engagement of a government to promote and realize social and economic rights ( $a$ government intervention and interference into the private sector is rather necessary). This group of rights are known to be objective and realized gradually since they are mostly conditioned by the social and economic context (Jašarevic, 2013: 86-87).

${ }^{2}$ The term "social security" is used in both narrow and broad sense. In the narrow sense, it involves the tendencies of contemporary social security towards offering universal social coverage to all citizens of one country. In its broad sense, which is predominant, the term denotes a large group of social measures applied in cases of social misfortunes and risks, such as: motherhood, illness, disability, unemployment, old age, etc. (Lakićević, 1987: 18).

More on social security in: Šunderić, 2009: 83-100.
} 
Although socio-economic rights are commonly referred to as social rights, scholarly texts and papers make a clear distinction between social and economic rights when classifying human rights. Therefore, the right to healthcare protection belongs to the group of social rights.

Social rights are frequently defined as the obligation and responsibility of the state to secure and guarantee an adequate social status to its citizens. They are intrinsically based upon the principle of equality and human solidarity that each state is required to support. Their goal is not to protect an individual from the government, but rather to secure a personal social integrity and the realization of basic human needs with an active support from the state. Thus, the range of social rights depends on the economic ranking of the state, that is on the economic politics of the state (Stojanović, 2009: 379).

The Constitution of the Republic of Serbia (hereinafter: the Serbian Constitution) ${ }^{3}$ guarantees the right to healthcare and protection, and proclaims the right of each citizen to the protection of their physical and mental health. Children, pregnant women, mothers on maternity leave, single parents with children up to seven years of age and senior citizens are granted health protection from public finances, if not realized in some other legal way. Healthcare insurance, healthcare protection and establishment of health funds are regulated by law. The Serbian Constitution promotes and supports the improvement of health and physical culture (Article 68).

Considering this constitutional provision, it is concluded that the right to healthcare protection is defined as a statutory right. It means that the framers of the Constitution refer to the adoption of of a particular legislative act that regulates this right in detail. Consequently, the Healthcare Act (hereinafter: the HCA) was passed in the Republic of Serbia. ${ }^{4}$

The HCA defines and regulates the healthcare protection system, healthcare services organization, social care for public health, general interest in health care, rights and obligations of patients, healthcare and protection of foreign citizens, establishment of the Agency for the accreditation of health institutions of Serbia, monitoring the law enforcement, and some other issues relevant for the organization and realization of healthcare protection (Article $1 \mathrm{HCA}$ ).

Healthcare protection is determined as an organized and extensive social activity aimed at securing the highest possible level of health preservation of all citizens and families. It involves all measures taken to preserve and improve the health of all citizens, to diagnose and cure diseases, health problems and other health issues as well as the measures for an adequate and timely recovery and rehabilitation (Article 2 HCA). All citizens of the Republic of Serbia and all individuals with the Serbian residency are entitled to healthcare protection guaranteed by the HCA, in accordance with the law. The citizens are also required to preserve and improve both their own and the health of other individuals, as well as their living and working conditions (Article 3 HCA).

All individual citizens, families, employers, institutions of education, charity, religious, sports and similar organizations, various associations, healthcare services, healthcare insurance organizations, as well as all municipalities, cities, autonomous regions and the Republic of Serbia participate in the process of healthcare protection realization (Article 4 HCA).

\footnotetext{
${ }^{3}$ The Constitution of the Republic of Serbia, Official Gazette of the Republic of Serbia, 98/06

${ }^{4}$ Healthcare Act, Official Gazette of RS, 107/05, 72/09- repealed, 88/10, 99/10, 57/11, 119/12, 45/13- repealed, $93 / 14,96 / 15$ and $106 / 15$
} 
Healthcare protection is based upon the activities of healthcare services. The HCA defines healthcare services as all those activities whose goal is the healthcare protection of citizens which include the measures applied using medical technologies in accordance with the medical doctrine, and which contribute to the preservation and enhancement of public health. Healthcare protection measures and activities should be based upon scientific results; thus, they must be safe, reliable, effective and in accordance with the principles of professional ethics (Article $6 \mathrm{HCA}$ ).

There are three levels of health care (Article 79 HCA): primary (Articles 94-109 HCA), secondary (Articles 110-114 HCA), and tertiary (Articles 115-118 HCA). Healthcare services may also be performed at multiple levels (Articles 119-129v HCA).

Healthcare services in the Republic of Serbia include all healthcare institutions and other similar healthcare centers (private practices), founded to offer healthcare and health protection, as well as medical staff that deliver healthcare services in accordance with the law (Article 6 HCA). A healthcare institution delivers health services, while private clinics perform certain activities pertaining to health services (Article 45, par. 2 HCA). Financial and material means necessary for healthcare services, their activities and improvement are provided in accordance with the law (Article 7 HCA).

Healthcare is realized in compliance with determined principles, such as: the principle of healthcare availability; the principle of healthcare equity; the principle of healthcare universality; the principle of healthcare continuity; the principle of a continuous healthcare quality improvement; and the principle of healthcare efficiency, which is particularly significant from the aspect of economy. ${ }^{5}$

\section{SOCIAL SECURITY AND SOCIAL INSURANCE}

One of the basic human needs is the need for security. Some authors consider it so important that they rank it next to the human physiological needs. The concept of social security came into being in XIX century in tandem with the process of an intense industrialization and mass employment of workers. In case of diseases, injuries at work and loss of jobs, workers would lose their wages, as the only source of income for them and their families. As their wages were so low that they could barely live on them, workers' initial attempts to provide security in case of social hazards by founding the petty-cash boxes for mutual assistance did not breed satisfactory results. Therefore, it was necessary to change the existing and establish new systems of social security (Kosanović, 2011: 19).

The right to social security is guaranteed and regulated in Articles 69 and 70 of the Serbian Constitution. The fundamental forms of social security are social insurance and social assistance ${ }^{6}$.

Social insurance is defined as a system of financial, social and psychological protection of an insured person, and it involves protection in case of illnesses, injuries, disability and social protection of senior citizens (retirement). Social insurance also provides protection for the family members in certain cases, i.e. in relation to the specified risks (Brajić, 1991: 527).

\footnotetext{
${ }^{5}$ For more information on the social security principles in Articles 19-24, Healthcare Act, Official Gazette RS, 107/05, 72/09 - repealed, 88/10, 99/10, 57/11, 119/12, 45/13 - repealed, 93/14, 96/15 and 106/15/

${ }^{6}$ As social insurance and social assistance are not the subject matter of this paper, they are not analyzed in detail here. In the Serbian legal system, these issues are regulated by the Social Protection Act, Official Gazette RS, 24/11.
} 
The system of social insurance is one of the most widely-spread forms of insurance established in most of the world. With reference to the insured risks, the basic types of social insurance are: 1) health insurance; 2) unemployment insurance; and 3) retirement and disability insurance. Social security is predominantly financed by the contributions paid by the employed persons. Thus, the principle of financial investment, or reciprocity and rationalization, is more emphasized than the principle of solidarity. Consequently, there are two types of insurance systems: public systems of social insurance, ${ }^{7}$ which are compulsory and predominant in reality, and voluntary systems of social insurance, established to offer additional benefits and provide insurance for the persons not insured otherwise (Jašarević, 2013: 190-191).

\section{HEALTHCARE INSURANCE - CONCEPT, FORM, FUNDING}

Healthcare insurance is a type of social insurance which guarantees the right to healthcare protection (the right to healthcare and healthcare services) and other healthcare insurance rights (compensation for occupational injuries or diseases, for transport expenses incurred while using healthcare services, etc.) to the insured persons (insurants and their family members) (Kosanović, 2011:31).

Several models of health insurance have been developed throughout history: the Bismarck Model, the Beveridge Model, the Semashko (socialist) Model and the Market Model.

The Bismarck model is the form of compulsory health insurance which provides universal coverage of healthcare costs. It is financed jointly by employers and employees through payroll deduction. This contribution is proportional to the salaries, i.e. the percentage deducted from salaries. This model is based on the nonprofit principles and solidarity among all insured persons. Funds are provided by several independent, mainly nonprofit agencies, organizations, hospital petty-cash boxes, etc. Funds are managed by insurants' representatives, whose task is to draw contracts with providers of healthcare services and thus secure healthcare protection for their insurants. This model is well-established in Germany, Austria, France, Belgium, Luxembourg, Netherlands, Switzerland, Slovenia, etc. (Janković, 2011: 71).

In the Beveridge model, healthcare and protection is financed through tax payment, i.e. by the government. It is based on solidarity and provides universal health coverage in both state and private healthcare institutions. Unlike the Bismarck model, insurants are not included in the management of the funds, which are managed by the government. This model is used in Great Britain, Ireland, Iceland, Finland, Norway, Sweden (Janković, 2011: 72).

The Semashko (socialist) model is known as the model of "the government-managed healthcare", which was applied in the former SSSR. It is rather similar to the Beveridge model in that the government regulates and finances the healthcare system. The healthcare fund is owned by the government and is thus financed from the central government budget.

\footnotetext{
${ }^{7}$ In public systems, the finances are treated uniformly and are, thus, characterized by solidarity. The rights are mainly dependent on the investment, but in an indirect way, so that the length of time and the amount of contributions are assessed based on the years of employment and salary throughout the insured period. This system may be corrected in certain cases by the principle of solidarity, so that the output amount surpasses the input one (e.g. disability pension, family pension, treatment for occupational injuries or hazards). In private systems, funds are deposited in the insurants' personal bank accounts, and are available at any time. The benefits are directly proportional to the deposited amounts of money and increased by the interest rate or income earned by investments, valuable papers trade, etc. This system of collecting and managing funds is very transparent, but it is more susceptible to the market hazards (Jašarević, 2013: 191-192).
} 
This system does not allow any form of private healthcare protection, nor any form of private or voluntary health insurance (Jovičić, 2014: 15).

In the Market (entrepreneurship) model, healthcare insurance is provided by private profit organizations (insurance companies and agencies). It is financed from the insurants' own funds and finances, most frequently through the insurance premium. It is not based on solidarity and does not provide universal healthcare protection. The classic Market model system is found in the USA (Janković, 2011: 72).

It is interesting that the Netherlands is the only country that has the system of the compulsory private healthcare insurance, which was introduced by the reform in 2006 whose goal was to improve quality and efficiency of the healthcare system for all citizens with long-term implications (Kovač, 2013: 553).

The Republic of Serbia has a mixed system of healthcare financing with a predominantly public source of financing, since the funds are mostly provided from contributions and the state budget. The healthcare system in Serbia is based on the Bismarck model since more than $80 \%$ of the healthcare funds are provided by the payroll deduction for the compulsory healthcare insurance. However, the Healthcare Act also envisages the health insurance funding from the state budget for persons who are not included in the compulsory healthcare insurance and who are exposed to health risks, which is the feature of the Beveridge model (Kosanović, 2011: 49).

There are various systems of healthcare services payment. In some countries, healthcare and rehabilitation are paid straight from the healthcare insurance funds (the so-called natural system); in some other systems, consumers pay for healthcare services, and these costs are then partially or wholly refunded (refund system). The situation is similar when it comes to medicines and other medical devices. Some medicines are free of charge and paid for by the healthcare insurance funds, whereas some are partially or wholly paid for by the insurants (the so-called participation). The system of participation is introduced to encourage healthcare services' consumers to use medical services rationally (Jašarević, 2013: 194).

The legal system of the Republic of Serbia recognizes two types of healthcare insurance: voluntary and compulsory insurance. The voluntary healthcare insurance is regulated by the Insurance $A c t^{8}$, as well as in relevant legal provisions of the Obligation Relations Act ${ }^{9}$ referring to the concept of contract of insurance and general contract law rules, as well as relevant articles of the Healthcare Insurance Act and other legislative acts and bylaws.

The compulsory healthcare insurance is regulated by the Healthcare Insurance Act (hereinafter: HIA $)^{10}$ and some pertaining legislative acts and bylaws. The compulsory healthcare insurance guarantees the right to healthcare protection and reimbursement of healthcare costs in the cases specified by this Act to employed persons and all citizens entitled to the compulsory healthcare insurance (Article 3 HIA). The compulsory healthcare insurance includes the following: insurance for diseases and injuries and insurance for occupational injuries and diseases (Article 9 HIA).

The compulsory healthcare insurance system is based on the following principles: the principle of obligation; the principle of solidarity and reciprocity; the principle of publicity;

\footnotetext{
${ }^{8}$ Insurance Act, Official Gazette RS, 55/04, 70/04 - corr., 61/05, 61/05- repealed, 85/05- repealed, 101/07, 63/09 - CC decision, 107/09, 99/11, 119/12, 116/13 and 139/14- repealed.

${ }^{9}$ Obligation Relations Act, Official Gazette SFRY, 29/78, 39/85, 45/89 - CCY decision and 57/89, Official Gazette SRY, 31/93 andOfficial Gazette SM, 1/03 - Constitutional charter.

${ }^{10}$ Healthcare Insurance Act, Official Gazette RS, 107/05, 109/05 - corr, 57/11, 110/12 - CC decision, 119/12, 99/14, 123/14, 126/14 - CC decision, 106/15 and 10/16 - repealed.
} 
the principle of insurants' rights protection and protection of public interest; the principle of continuous healthcare insurance quality improvement; and the principle of economic efficiency of the compulsory healthcare insurance ${ }^{11}$, which is particularly interesting from the aspect of economics.

Pursuant to the HIA, the insured persons are the insurants and their family members, entitled to the healthcare rights defined by this Act and pertaining regulations enacted for the implementation of this Act. Other persons insured for specific cases are also entitled to the rights provided by the compulsory healthcare insurance in accordance with this Act (Article 16 HIA).

The compulsory healthcare insurance rights are: healthcare protection right; temporary disability benefits right; healthcare travel costs right. These rights are exercised under the condition that the healthcare insurance contribution has been paid, unless stated otherwise (Article 30 HIA).

The compulsory healthcare insurance rights are financed from the contributions to the compulsory healthcare insurance and from other sources, in accordance with this Act and the law regulating the compulsory social insurance contribution. The funds thus collected represent the income of the Healthcare Insurance Fund of the Republic of Serbia (Article $201 \mathrm{HIA}$ ).

\section{ECONOMIC REASONS FOR GOVERNMENT INTERVENTION IN HEALTHCARE PROTECTION AND HEALTHCARE INSURANCE}

The right to healthcare protection and healthcare insurance fall into the group of social rights. Considering that the enjoyment and exercise of social rights require an active participation of the state (the so-called positive state obligation), the state intervention is completely acceptable and justified. However, there are purely economic reasons that make the healthcare services market imperfect, nonstandard and thus prone to the necessary state interventionism ${ }^{12}$.

Healthcare protection and compulsory healthcare insurance ${ }^{13}$ are public goods; to be precise, they are designated as impure public goods because they do not have two characteristics that all pure public goods share (to be non-rivalrous or non-excludable). They may be classified as club public goods because there is no rivalry among the users of these public goods, and the non-paying users may be easily excluded because the expenses of such intervention are not too high. For instance, when visiting the doctor's, the information on the healthcare card clearly and efficiently reveals whether the obligatory healthcare insurance has been paid, and if not, health services may be denied. However, rivalry might occur on some occasions. For example, in case of compulsory schoolchildren health checkup, health services offered to each additional pupil produce marginal costs that always equal zero. The state expenses for paying the doctor's services will be the same, irrespective of whether the doctor has examined 100 or 150 pupils. The situation is somewhat different when considering the use of certain medical devices and techniques (e.g. magnetic

\footnotetext{
${ }^{11}$ For more information on the obligatory healthcare insurance principles, see: Articles 10-15, Healthcare Insurance Act, Official Gazette RS, 107/05, 109/05-corr., 57/11, 110/12-CC decision, 119/12, 99/14, 123/14, 126/14-CC decision, 106/15 and 10/16 - repealed.

${ }^{12}$ More on the relationship between health and economy in: McDaid, Sassi, Merkur, 2015.

${ }^{13}$ Hereinafter, the term healthcare insurance refers to the compulsory healthcare insurance as a public good.
} 
resonance), or the use of some chemicals for blood testing. An increased demand for these kinds of healthcare services may cause rivalry and competition that result in long waiting lists of patients, or even the shortage of necessary devices, which makes it impossible to offer certain services at a particular time. It practically means that those who have applied for the service earlier will obtain it sooner than those patients who have registered later, and who may even stand a risk of not being given the necessary healthcare assistance at all. The marginal costs incurred owing to each new patient are higher than zero. Consequently, the healthcare insurance and healthcare protection are characterized by a limited capacity. Healthcare protection and healthcare insurance are also meritorious public goods since the compulsory healthcare insurance and protection are forced onto the citizens by their government. Even though individuals are aware of various health hazards and the importance of regular health check-ups, it is doubtful how many people would voluntarily subject themselves to certain examinations if the the state had not prescribed compulsory screening programmes for early disease detection, etc.

The healthcare services market is characterized by a phenomenon of imperfect information $^{14}$. This issue may be analyzed from various aspects. First, regarding the doctorpatient relationship, it is the doctor who has more knowledge and experience than the patient. The patient is not required to have any sort of expert knowledge. Patients completely rely on the doctor's diagnosis and treatment. In order to reduce this information disbalance and provide a higher quality of health services, the government introduces certain measures to monitor the doctor's work. For example, it may be accomplished by compulsory training, continuous education, issuing doctor's licence, etc.

When purchasing everyday goods, consumers are able to assess the quality of the purchased products, or they trust certain stores (where fruits are always fresh, for instance). However, individuals do not "purchase" health services, such as heart or kidney transplantation, ulcer treatment (etc.) every day. There are particular institutions and agencies which check the quality of products such as cars, do consumer surveys, emphasize the alterations to be done on new products of the same or different kind, etc. Yet, health services are different. Our neighbour may be satisfied with a certain doctor and the treatment of his own disease, which does not necessarily imply that we will be satisfied as well. Our neighbour suffered from a less serious disease and he managed to develop a satisfactory communication with the doctor, which is not the case with us. Our disease is, for instance, different from his and we did not manage to communicate with the doctor successfully (Stiglic, 2004: 314). This means that the transfer of information between former and future patients, as health services consumers, regarding their contentment with the treatment and its success is not always accurate or relevant.

Insurance companies encounter the problem of information disbalance as well. They also rely on the doctor's diagnosis and do not have adequate mechanisms to assess the accuracy of doctor's report and the validity of health costs to be covered. This gives rise to the problem of negative selection ${ }^{15}$. Upon determining the amount of the insurance premium that the insurant is required to pay, the insurance company may, due to the lack of information on the individual being either a low-risk or high-risk patient, ascertain the amount not corresponding

\footnotetext{
${ }^{14}$ More on the problem of imperfect information in: Begović, Labus, Jovanović, 2014: 353-411.

${ }^{15}$ Negative selection is the phenomenon when the choice of consumers (one party in the contract) causes larger costs on the part of the seller of services (the other party in the contract) (Begović, Labus, Jovanović, 2014: 377). More on the negative selection issue in: Begović, Labus, Jovanović, 2014: 375-381.
} 
to the actual health state of the insurant. There is a risk of this amount being attractive for high-risk patients that will gain a surplus in that way, as well as a risk of it being too high for low-risk patients who are prepared to pay a smaller amount. Therefore, only high-risk patients will remain on the life insurance market, whose death will cost the insurance company more than the amount they have already paid for insurance; it ultimately generates the phenomenon of negative selection ${ }^{16}$.

The mechanisms available to insurance agencies in preventing the negative selection are compulsory health check-ups and the level of health risks of future insurants. This may be also the mechanism of coordinated selling of life and retirement insurance services. The low-risk patients will probably choose this kind of offer as they expect to live until their retirement age and to be in the position to use their private retirement funds as well. Being aware of the implausibility of living long enough to their retirement age, the high-risk consumers will not choose this offer; thus, paying larger insurance premiums for both types of insurance is not an acceptable option for them (Begović, Labus, Jovanović, 2014: 378).

The state intervenes to prevent the phenomenon of the negative selection by the mechanism of the so-called risk communities expansion, i.e. compulsory and imposed inclusion of low-risk individuals (from the insurance perspective) into the insurance package. A typical example is the compulsory healthcare insurance, which is frequently considered to be the heritage of the "welfare state" and which is wrongly termed as "the free healthcare protection" offered to all citizens. This insurance premium (contribution) is not related to the insurants' health risks but rather to their salaries. The healthcare insurance is deducted from payroll in the form of the percentage of the insurants' income (salary, additional earnings, etc.). This kind of the state intervention in healthcare insurance by introducing the compulsory healthcare insurance is an internal (between the insurants) subsidy, where the rich subsidize the poor and the healthier subsidize the less healthy citizens (Begović, Labus, Jovanović, 2014: 378-379).

The healthcare services market, being a nonstandard market, is also characterized by the phenomenon of a limited competition. Lower medical prices in one doctor's office in comparison to other doctors' offices are a sign for patients that the doctor endeavors to increase the number of patients by offering competitive prices. However, it indirectly implies that this doctor lacks the necessary expertise, knowledge or skills so that patients avoid visiting them. The spread of information on the healthcare services quality depends largely on the healthcare services prices. High prices do not always equal high-quality services. The limited competition is closely related to an insufficient number of specialists in certain areas of medicine. Moreover, the number of hospitals is insufficient. For example, small towns have only one hospital. Time appears to be a factor that often limits a patient's choice of a desirable healthcare service. The competition and efficient spread of information are also affected by the ban on commercials on doctor's services (Stiglic, 2004: 315).

In some cases, nonprofit organizations may have a dominant role in the offer of healthcare services. It is typical of the United States of America (USA). As evident from their name, nonprofit organizations do not have as their goal the accumulation of profit. The absence of profit worsens an efficient resources allocation, i.e. the way in which the government and private insurance agencies pay compensations to hospitals (Stiglic, 2004: 315-316).

\footnotetext{
${ }^{16}$ A detailed description of this example in: Begović, Labus, Jovanović, 2014: 375-377.
} 
Additionally, the healthcare insurance and healthcare services market share a common characteristic, which is known as the phenomenon of payment by the third party or a cost overflow. A survey conducted in the USA has shown that individuals pay less than one quarter of the total healthcare services costs, even less for doctors' fees and an insignificant amount of money for hospital costs (total 3\%). Since a large portion of expenses is paid by a third party, healthcare services consumers are insufficiently encouraged to use them rationally, and with caution and care (Stiglic, 2004: 316).

Medical malpractice cases are very significant for the process of resources allocation. The doctor and the patient develop a relationship in which it is the doctor's duty and obligation to treat the patient, but not to cure them. Consequently, the patient may or may not be satisfied with the offered medical services and treatment results. Therefore, the patient can sue the physician and seek compensation. Court judgments in such cases may stimulate or destimulate the patient to file compensation claims. On condition that the concept of objective responsibility is accepted, then the compensation should be equal to the damage sustained by malpractice, neither more nor less. In reality, it is rather difficult to determine this amount with precision, the fundamental reason being the information asymmetry. Higher compensations will unavoidably encourage patients to initiate legal disputes even in those cases when there are no justifiable reasons for a lawsuit. They are thus indirectly motivated to abuse their rights. Such cases were first detected in the USA. Doctors were forced to establish insurance funds against medical malpractice lawsuits. Obstetricians experienced the harshest attacks which resulted in terminating their private practice and young doctors refusing to specialize in this field of medicine. This led to the development of the so-called defensive medicine. In order to protect their profession and competence, doctors frequently prescribe the analyses and tests which are not indicated by the patient's health condition. Thus, they only tend to fulfill the patient's requests, regardless of the fact that such use of resources is completely irrational and countereffective from the aspect of a general welfare of the society (Stiglic, 2004: 318-319).

Moral hazard originally appeared in the field of insurance, including healthcare insurance. It is any situation in which the market participants do not stand the consequences of their actions, i.e. they do not pay the expenses incurred by their actions. Any kind of "insurance" can cause this phenomenon (Begović, Labus, Jovanović, 2014: 382). As regards health insurance, especially in case of a completely free oral healthcare insurance, it means that individuals will not take care of their oral hygiene or their improper diet containing an excessive amount of sweets. These individuals might be indirectly induced to neglect their oral health since the healthcare insurance will pay for their new artificial porcelain teeth. The moral hazard effects may be reduced by introducing participation for certain healthcare services or certain medicines, regardless of the fact that the patient has a compulsory healthcare insurance.

Negative external effects can be caused by particular kinds of infectious diseases. Precautionary healthcare measures can significantly prevent the spread of these diseases and thus the costs of potential patients' treatment. Positive external effects can also contribute to reducing the healthcare insurance costs. Proper investments into scientific researches result in the discovery of new medicines or vaccines that help in the eradication of certain diseases or the cure of patients. Financing medical research is not an expense but an investment whose positive effects surpass the funds invested. 
The system of healthcare insurance and healthcare protection also features high transaction expenses ${ }^{17}$. These expenses are caused by the maintenance and management of the system of the compulsory healthcare insurance. Numerous activities are necessary, such as keeping records, innovating the system, etc. This means a greater number of employees who are paid for their work. Also, regular hospital servicing, purchase of adequate medical equipment and medicines, and other necessary activities make the system of healthcare protection extremely expensive.

The standard competition theory presumes that the greater the offer (i.e. the number of physicians), the lower the price of medical services. However, conducted studies show that this is not the case in reality. Owing to the phenomenon of limited information, patients assess the quality of medical services on the basis of price; hence, physicians are not ready to lower the prices in order not to be considered second-rate specialists (Stiglic, 2004: 325).

Other factors that affect healthcare protection costs are longevity, poverty, unemployment, etc. As regards poverty, it is believed that human health represents a non-material good and is thus available to the poor and rich alike. This is the so-called specific egalitarianism. Some other theories claim that healthcare services are to be treated as any other public good. The rich should be given a free choice to decide how and whether they will spend their money on healthcare protection. The proponents of this idea believe that the link between healthcare protection and life/death is rather loose, and that it is more important to invest into the healthy lifestyles and healthy food which have a fundamental influence on the life span. Some authors consider that each individual is entitled to a minimal level of healthcare protection. This principle is advocated by the majority of western democratic states (Stiglic, 2004: 327).

\section{CONCLUSION}

The specific nature of healthcare protection and healthcare insurance systems requires the state intervention. The state monitors and manages these systems more or less successfully. Besides the legal reasons, given that these issues are related to the social rights, there are purely economic reasons why the state has to intervene. Most importantly, these are a specific type of public goods, whose protection should not be completely managed by the market.

There is no perfect model of healthcare protection and healthcare insurance. These models have changed throughout history in accordance with the development and establishment of different governments. There are cases where the private sector and the market were forbidden from operating within these models, such as the case of the former USSR. Today, European states apply the combined system, which means that the healthcare insurance is provided not only by the government but also by private insurance agencies. The role of the private sector is traditionally dominant in the USA. Consequently, a large number of citizens lose the right to healthcare insurance upon becoming unemployed. This breeds great social insecurity. Therefore, the problem of healthcare insurance is a political issue in the USA.

The truth about healthcare protection and healthcare insurance is that they cost. Even though these rights are guaranteed by international documents, constitutions and laws, they are proclaimed in the so-called programme principles whose realization depends

\footnotetext{
${ }^{17}$ The transaction expenses are all the expenses of the purchase and sale of goods, including the costs of the market management (Stiglic, 2004: 323)
} 
primarily on the economic wealth of a specific society. Moreover, larger investments into healthcare insurance do not necessarily imply better health and a longer life span of the citizens.

The frequently used term "free" health insurance and health protection does not stand since these services are paid by a society and its members. Consumers of healthcare services do have the impression that they are "free" because they do not pay for them directly but indirectly, as a result of the costs overflow. Citizens with larger incomes pay higher social insurance contributions as compared to poorer citizens, which is a way of subsidizing healthcare services.

New discoveries in the fields of medicine, chemistry, biology and other sciences have uprooted certain diseases, which ultimately led to reducing the negative external effects of some diseases that used to increase healthcare costs. However, a longer life span and the development of some new diseases do not reduce but rather increase the costs of healthcare, which are additionally amplified by poverty, bad living conditions and the process of social and natural evolution, which have both positive and negative effects.

Acknowledgement: The paper is the result of the author's work on the project "Protection of Human and Minority Rights in the European Legal Framework", project registration number: OI 179046, funded by the Ministry of Education, Science and Technological Development of the Republic of Serbia.

\section{REFERENCES}

Begović, B. Labus, M., Jovanović A. (2014). Ekonomija za pravnike. Beograd: Pravni fakultet Univerziteta u Beogradu, Centar za izdavastvo i informisanje, i Dosije studio, Beograd

Brajić, V. (1991). Radno pravo. Beograd: Savremena administrating. In: Kosanović, R. (2011). Socijalno pravo. Beograd: Radnicka stampa. 22

Janković, D. (2011). Zdravstveno osiguranje kao faktor troskova zdravstvene zastite. Skola biznisa. 69-82, http://www.vps.ns.ac.rs/SB/2011/8.7.pdf, retrieved March 16, 2017

Jovičić, K. (2014). Osnovna pitanja zdravstvenih sistema u evropskim zemljama. In: Jovicic, K. (Ed.). Sistemi zdravstvene zasite $i$ zdravstvenog osiguranja - uporednopravna analiza u evropskim zemljama. Beograd: Sindikat lekara i farmaceuta Srbije - Gradska ogranizacija Beograda, Institut za uporedno pravo (8-39); retrieved 16 March 2017 from http://www.comparativelaw.info/sistemzzizo.pdf

Jašarević, S. (2013). Socijalno pravo. Novi Sad: Univerzitet u Novom Sadu, Pravni fakultet, Centar za izdavacku delatnost

Kosanović R. (2011). Socijalno pravo. Beograd: Radnicka stampa

Kovač, N. (2013). Financiranje zdravstva - situacija u Hrvatskoj. Ekonomski vjesnik. 2(XXVI). 551-562; retrieved 20 March 2017 from file://C:/Users/Aca/Downloads/nevenka_kovac\%20(2).pdf

Lakićević, D. (1987). Uvod u socijalnu politiku. Beograd: Savremena administracija. In: Kosanovic, R. (2011). Socijalno pravo. Beograd: Radnicka stampa. 20

Marković R. (2015). Ustavno pravo. Beograd: Pravni fakultet Univerziteta u Beogradu, Centar za izdavastvo i informisanje and Dosije studio, Beograd

McDaid, D. Sassi, F. Merkur, S. (2015). Promoting Health, Preventing Disease - The Economic Case. Open University Press.; retrieved 20 March 2017 from http://www.keepeek.com/Digital-Asset-Management/oecd/ economics/promoting-health-preventing-disease_9780335262274-en\#.WM-dgIE1_IW\#page5,

Stiglic, E. Dz. (2004). Eкonomija javnog sektora. Beograd: Ekonomski fakultet Beograd

Stojanović, M. D. (2009). Ustavno pravo. Nis: Sven

Šnderic, B. (2009). Socijalno pravo. Beograd: Pravni fakultet Univerziteta u Beogradu, Izdavacki centar 


\section{LEGAL SOURCES}

Zakon o zdravstvenoj zaštiti (Healthcare Protection Act), Službeni glasnik RS. Br. 107. 2005. 72.2009 - dr. zakon. 88. 2010. 99. 2010. 57. 2011. 119. 2012. 45. 2013 - dr. zakon. 93. 2014. 96. 2015. i 106. 2015.

Zakon o zdravstvenom osiguranju (Healthcare Insurance Act), Službeni glasnik RS. Br. 107. 2005. 109. 2005 ispr. 57. 2011. 110. 2012 - odluka US. 119. 2012. 99. 2014. 123. 2014. 126. 2014 - odluka US. 106. 2015. i 10.2016 - dr. zakon.

Zakon o obligacionim odnosima (Obligation Relations Act), Službeni list SFRJ. Br. 29. 1978. 39. 1985.45. 1989 - Odluka USJ. 57. 1989. Službeni list SRJ. Br. 31. 1993. Službeni list SCG. Br. 1. 2003 - Ustavna povelja Zakon o osiguranju (Insurance Act), Službeni glasnik RS. Br. 55. 2004. 70. 2004 - ispr., 61. 2005. 61. 2005-dr. zakon, 85. 2005- dr. zakon, 101. 2007. 63. 2009- odluka US. 107. 2009. 99. 2011. 119. 2012. 116. 2013. i 139. 2014- dr. zakon.

Zakon o socijalnoj zaštiti (Social Protection Act), Sl. glasnik RS. Br. 24. 2011.

Ustav Republike Srbije (Constitution of the Republic of Serbia), Službeni glasnik RS. Br. 98. 2006

\section{EKONOMSKA ANALIZA ZDRAVSTVENE ZAŠTITE}

Zdravstvena zaštita $i$ zdravstveno osiguranje zbog svoje specifične prirode zahtevaju državnu intervenciju. Pored pravnih razloga, jer su u pitanju socijalna prava, postoje i čisto ekonomski razlozi koji zahtevaju delovanje države. Na prvom mestu to proizilazi iz činjenice da se radi o specifičnim javnim dobrima, čije obezbeđivanje ne bi u potpunosti moglo da bude prepušteno tržištu. Savršeni model zdravstvene zaštite $i$ zdravstvenog osiguranja danas ne postoji. Promenom društveno-ekonomskog uređenja država tokom istorije, menjali su se i modeli zdravstvenog osiguranja i zdravstvene zaštite. Iako često čujemo izraz ,,besplatno “ zdravstveno osiguranje i zdravstvena zaštita, oni koštaju jedno društvo $i$ njegove članove. Uprkos činjenici da su ova prava proklamovana međunarodnim dokumentima, ustavima i zakonima, to se čini u vidu tzv. programskih načela čije će ostvarivanje prevashodno zavisiti od ekonomske snage jednog društva. Takođe, visoka ulaganja u oblast zdravstvenog osiguranja ne znači odmah $i$ visok stepen zdravlja ili duži životni vek stanovnika jedne države. Zbog toga, neophodno je efikasno i ekonomično koristiti dostupne resurse i postizati što bolje efekte zdravstvene zaštite u okviru dostupnih resursa.

Ključne reči: zdravstvena zaštita, zdravstveno osiguranje, državna intervencija, javna dobra, tržište zdravstvenih usluga.

Translated by: Ljiljana Janković 